\title{
SPORTS MECHANICS REHABILITATION EFFECTS ON KNEE AND MUSCLE
}

\author{
OS EFEITOS DA REABILITAÇÃO MECÂNICA DO ESPORTE SOBREO JOELHO E O MÚSCULO
}

Original Article LOSEFECTOS DELA REHABILITACIÓN MECÁNICA DEL DEPORTE SOBRE LA RODILLA Y EL MÚSCULO

Artigo Original Artículo Original

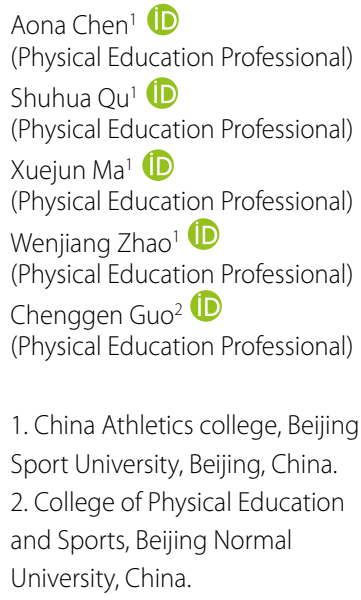

1. China Athletics college, Beijing Sport University, Beijing, China.

2. College of Physical Education and Sports, Beijing Normal

University, China.

\section{Correspondence}

Xuejun $\mathrm{Ma}$

Beijing 100084, China.

maxuejun38@163.com

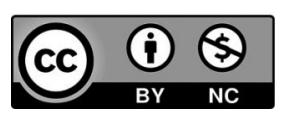

\begin{abstract}
Introduction: The knee joint is a complex and important joint in the human body. It plays an active role in maintaining posture balance of the human body in sports, allowing one to bear a larger load and complete various complex technical movements. Objective: To investigate the stability and influence of kinemechanics in knee joint rehabilitation training. Methods: A total of 80 patients with anterior cruciate ligament injury who received treatment in Henan Provincial People's Hospital were selected and divided into control group and observation group according to the random number table method, with 40 cases in each group. Results: Six months after surgery, the peak torque (PT), peak torque to body weight ratio (PT/BWT), total work (TWT), Lysholm score and Tegner score, and knee circumference of the two groups were significantly improved compared with those before surgery $(P<0.01)$. The degree of improvement was greater in the observation group:compared with the control group, the difference was highly statistically significant $(P<0.01)$. Conclusions: Professional exercise rehabilitation has a definite effect on patients after anterior cruciate ligament reconstruction. It can significantly improve the muscle strength of quadriceps and hamstring, improve the function of knee joint and promote its recovery. Level of evidence Il; Therapeutic studies - investigation of treatment results.
\end{abstract}

Keywords: Exercise; Knee joint; Rehabilitation.

\section{RESUMO}

Introdução: A junta do joelho éuma junta complexa e importante para o corpo humano. Tem um papel ativo na manutenção do equilibrio postural do corpo humano nos esportes, permitindo que se suporte cargas maiores eque se realize vários movimentos técnicos complexos. Objetivo: Investigar a estabilidade e influência da cinemática no treino para reabilitação da junta do joelho. Métodos: Um total de 80 pacientes com lesão de ligamento cruzado anterior que receberam tratamento no Hospital do Povo da Província de Henan foram selecionados e divididos em grupo de controle e grupo de observação, de acordo com o método de tabela numérica aleatória, com 40 casos em cada grupo. Resultados: Seis meses após a cirurgia, o torque de pico (TP), a proporção torque de pico-peso corporal (TP-PC), trabalho total (TT), escore Lysholm e escore Tegner, ea circunferência do joelho dos dois grupos melhoraram significativamente em relação à antes da cirurgia $(P<0.01)$. O grau de recuperação foi maior no grupo de observação: comparado com o grupo de controle, a diferença éestatisticamente significativa $(P<0.01)$. Conclusões: A reabilitação com exercícios profissionais definitivamente tem efeito em pacientes após a reconstrução do ligamento cruzado anterior, pois pode aumentar a força muscular de quadríceps e tendões, melhorar a função dajunta do joelho elevar a sua recuperação. Nível de evidência ll; estudos terapêuticos-investigação de resultados de tratamento.

Descritores: Exercício físico; Articulação do joelho; Reabilitação.

\section{RESUMEN}

Introducción: La articulación de la rodilla es compleja e importante para el cuerpo humano. Tiene un papel activo en la manutención del equilibrio postural del cuerpo humano en los deportes, permitiendo que se soporte cargas mayores y que se realice varios movimientos técnicos complejos. Objetivo: Investigar la estabilidad e influencia de la cinemática en el entrenamiento para rehabilitación de la articulación de la rodilla. Métodos: Se seleccionó un total de 80 pacientes con lesión de ligamento cruzado anterior que recibieron tratamiento en el Hospital del Pueblo de la Provincia de Henan y se los dividió en grupo de control y grupo de observación, de acuerdo con el método de tabla de números aleatorios, con 40 casos en cada grupo. Resultados: Seis meses tras la cirugía, el torque de pico (TP), la proporción torque de pico-peso corporal (TP-PC), trabajo total (TT), puntuación Lysholm y puntuación Tegner, y la circunferencia de la rodilla de los dos grupos mejoraron significativamente en relación a antes de la cirugía ( $P<0.01)$. El grado de recuperación fue mayor en el grupo de observación: comparado con el grupo de control, la diferencia es estadísticamente significativa $(P<0.01)$. Conclusiones: La rehabilitación con ejercicios profesionales definitivamente tiene efecto en pacientes tras la reconstrucción del ligamento cruzado anterior, pues puede aumentar la fuerza muscular de cuádriceps y tendones, mejorar la función de la articulación de la rodilla y llevar a su recuperación. Nivel de evidencia ll; Estudios terapéuticos - investigación de resultados de tratamiento.

Descriptores: Ejercicio físico; Articulación de la rodilla; Rehabilitación. 


\section{INTRODUCTION}

Anterior cruciate ligament $(A C L)$ is one of the important structure to maintain knee stability, its damage can lead to knee - before and after rotating instability, which in turn can cause the meniscus and articular cartilage injury, accelerate the degeneration of the knee joint, the forward will induce a variety of secondary diseases such as osteoarthritis, seriously affects patients' daily life and motion.' In life, ACL injury can be caused by many factors, such as sports and traffic injuries, etc., and age, gender, lateral position and knee joint position at the time of injury have important effects on $A C L$ injury. $A C L$ cross-reconstruction is the main method for the treatment of $A C L$ injury, but postoperative rehabilitation can be conducive to the functional recovery of the knee joint and shorten the rehabilitation time. ${ }^{2}$ Exercise training builds muscle strength through neural and biochemical regulation. In the process of muscle strength training, the neural regulation mechanism can enhance muscle strength by promoting nerve activity, increasing the recruitment of motor units and improving the synchronicity of motor units. The biochemical regulatory mechanism is to improve muscle cell function by increasing glycogen and mitochondrial enzymes in muscle cells. ${ }^{3}$ Therefore, after muscle strength training, there was no significant change in muscle cross section, nor in muscle hypertrophy, but only an increase in the proportion of II type muscle fibers. Compared with the traditional isometric and isotonic strength training, muscle strength training can achieve the best effect of work done by any muscle in the process of joint movement and maximize the training efficiency. ${ }^{4}$

Proposed by clinical research to explore professional rehabilitation method application in the rehabilitation after knee cruciate ligament reconstruction, establish knee anterior cruciate ligament reconstruction, postoperative rehabilitation training standard and specification, the maximum recovery in patients with motor function, so as to solve the knee anterior cruciate ligament injury rehabilitation in prominent and urgent problem, provide a reference basis for the postoperative rehabilitation treatment. ${ }^{5}$

\section{METHOD}

\section{Experimental subjects}

A total of 80 patients with anterior cruciate ligament injury who underwent arthroscopic anatomical reconstruction of ACL in the Department of Orthopedics of Henan Provincial People's Hospital were selected and divided into control group and observation group according to random number table method, with 40 patients in each group. In the control group, there were 25 males and 15 females, aged $21 \sim 64$ years, with an average age of (42.35 \pm 9.15$)$ years. The course of disease was $7 \sim 16$ days, and the average course of disease was (10.54 \pm 3.57$)$ days. Injury site: left knee in 23 cases, right knee in 17 cases. In the observation group, there were 23 males and 17 males, ranging in age from 22 to 65 years old, with an average age of (42.81 \pm 10.02$)$ years. The course of disease was 8-16 days, with an average course of (10.67 \pm 3.62$)$ days. Location of injury: There were 22 cases of left knee and 18 cases of right knee. Compared with the general data of gender, age, course of disease, injury site and other information of patients in the two groups, there was no statistical significance $(P>0.05)$, which was comparable. Inclusion criteria: 1) Clear knee ACL injury, and ACL grade above Il; 2) Indications for arthroscopic surgery, no contraindication for arthroscopic surgery; 3) Understand the treatment research ideas and methods of this study, and actively cooperate with this study, can follow up after surgery, and sign the relevant informed consent. ${ }^{6}$

\section{Experimental method}

Patients in both groups underwent preoperative isokinetic test, comprehensive imaging examination, and $\mathrm{ACL}$ reconstruction after anesthesia.
The control group was given simple routine rehabilitation guidance after surgery, which mainly included rehabilitation propaganda and education, guidance for family members to do a good job in daily nursing, body rehabilitation exercise, etc. The observation group was guided by sports researchers to carry out professional sports rehabilitation, as follows:

1. 1-2 weeks after surgery

- Rehabilitation guidance: Braces were immediately used after the operation, and the patient was sent back to the hospital bed for rehabilitation instructions, such as quadriceps isometronic contraction, ankle pump, etc., to inform the patient of possible postoperative pain and swelling, so as to remove the patient's doubts.

- Continuous pressure cold therapy: patients take the whole knee extension position, ankle joint pad high implementation of ankle pump, pressure cold therapy, in order to reduce swelling.

- Rehabilitation exercise: $1 \sim 3$ d thigh muscle tension, quadriceps equilateral contraction and maintain $3 \sim 5 \mathrm{~s}$ after relaxation, try to do as much as possible, if the pain is intensified, stop or appropriately reduce the intensity of exercise; For 4-6 days, the ankle joint was flexed and extended vigorously, slowly and in a full range, the patella was slid (especially inward), and the legs were slightly swung when sitting up and getting up, and the legs were standing with support and crutches without bearing weight (pain and swelling should be avoided). From 7 to 14 days, straight leg raising, sliding bed and proprioception training were performed, and the center transfer (leg rotation out to reduce ACL stress) and gait training (walking with crutches, walking up and down stairs with crutches) were performed with crutches as well as with crutches.?

2. Two to four weeks after the operation, the target range of joint motion was normal, squatting under partial weight, quadriceps muscle strength exercise, hamstring muscle strength exercise (static knee bending and leg pressing backward), water walking, step exercise (on the healthy side, under the affected side), and exercise cycling (to increase coordination). 3. 4-8 weeks after the surgery, walking off the crutches (wearing functional braces and controlling time), squatting against the wall with weight, quadriceps muscle strength exercise, hamstring muscle strength exercise (static knee flexion and backward leg pressure), laterally, walking back and forth. 4. 9-12 weeks after the operation, long walking (wearing functional braces), quadriceps muscle strength exercises, step training, one-leg squatting, and functional single training (jogging, swimming).

\section{RESULTS}

The excellent and good rate of the observation group was 97.5\%, which was significantly higher than that of the control group (85.0\%), and the difference between the two groups was statistically significant $x^{2}=3.914, p=0.048$. (Table 1)

There was no statistically significant difference in knee circumference between the two groups before surgery ( $P>0.05$ ), but the knee circumference of the two groups was significantly improved 6 months after surgery $(P<0.01)$, and the improvement in the observation group was more significant than that in the control group $(P<0.05) .{ }^{8}$ (Table 2)

The anterior tibial displacement of ACL fractured knee joint under $134 \mathrm{~N}$ preloading before and after anesthesia at different states and angles is shown in Table 3. Repeated measure analysis of variance (ANOVA) showed a significant difference between pre - and post-anaesthesia $(P<0.05)$, and the tibial anterior displacement in the post-anaesthesia group was increased compared with that before anaesthesia. ${ }^{9}$

Table 1. Comparison of therapeutic effects between the two groups (cases).

\begin{tabular}{c|c|c|c}
\hline group & Number of examples & fine & of no avail \\
\hline observation group & 41 & 38 & 2 \\
\hline control group & 40 & 36 & 2 \\
\hline
\end{tabular}


Table 2. Comparison of circumferential diameter of knee joint between the two groups.

\begin{tabular}{c|c|c|c}
\hline Group & $\begin{array}{c}\text { Number of } \\
\text { examples }\end{array}$ & Preoperative & $\begin{array}{c}\text { Six months after } \\
\text { the operation }\end{array}$ \\
\hline Observation group & 41 & $41.65 \pm 6.29$ & $33.48 \pm 4.23$ \\
\hline Control group & 40 & $42.02 \pm 6.38$ & $37.56 \pm 5.23$ \\
\hline t value & & 0.256 & 3.560 \\
\hline P value & & 0.356 & 0.002 \\
\hline
\end{tabular}

Table 3. Tibia anterior displacement under $134 \mathrm{~N}$ preloading before and after anesthesia for ACL injury knee joint.

\begin{tabular}{c|c|c|c|c|c}
\hline \multirow{2}{*}{ Status } & \multicolumn{4}{|c|}{ Angle } & \multirow{2}{*}{ Amount to } \\
\cline { 2 - 6 } & $\mathbf{0}$ & $\mathbf{3 0}$ & $\mathbf{6 0}$ & $\mathbf{9 0}$ & \\
\hline Before the hemp & $4.60 \pm 0.08$ & $7.50 \pm 2.23$ & $6.34 \pm 2.06$ & $6.10 \pm 2.06$ & $6.12 \pm 2.23$ \\
\hline After the hemp & $6.30 \pm 0.43$ & $10.26 \pm 0.82$ & $8.92 \pm 0.92$ & $8.42 \pm 1.62$ & $8.43 \pm 1.56$ \\
\hline Amount to & $5.46 \pm 1.69$ & $8.83 \pm 2.18$ & $7.60 \pm 2.01$ & $7.53 \pm 1.82$ & $7.29 \pm 2.03$ \\
\hline t value & -2.050 & -3.659 & -3.413 & -3.125 & 11.989 \\
\hline P value & 0.021 & 0.007 & 0.013 & 0.016 & 0.012 \\
\hline
\end{tabular}

\section{DISCUSSION}

$\mathrm{ACL}$ injury can lead to knee instability, which is a common clinical disease that seriously affects the stability of knee joint. The clinical manifestations of this disease include different degrees of knee pain, swelling and function limitation, which will affect the patients' daily life and exercise. In severe cases, the internal structure of the knee joint will be further damaged, leading to degeneration of cartilage and meniscus, and the incidence of a variety of secondary ACL diseases is high, especially in athletes. Currently, the incidence of ACL in the U.S. population is estimated to be 1 in 3,000, while the annual incidence of ACL injuries in soccer is 60 in 100,000, and that in skiing is 70 in 100,000 , significantly higher than that in the general population. However, there is no report of overall population incidence in China. $A C L$ injuries in athletes are more common in football, basketball, martial arts, gymnastics, judo, wrestling and other sports, while ACL injuries in non-athletes are more common in general sports, such as football, basketball, jump sports and so on. ACL injury is not uncommon in clinical practice. Accurate diagnosis of ACL injury, especially for acute injuries, still has some difficulties. Traditional knee stability tests, such as the front drawer test, have high false negative rates and are subject to subjective factors. The anterior and posterior drawer test is still preferred by orthopedic surgeons. In conclusion, isokinetic techniques have obvious advantages over traditional muscle training methods. Since the early 1980s, isokinetic instruments have been introduced into China, and they have been widely used in sports medicine and rehabilitation medicine. In recent years, the application of isokinetic technology in China has achieved remarkable results in the prevention, treatment and rehabilitation of knee joint injuries such as knee osteoarthritis, anterior cruciate ligament injury and meniscus injury, but there is still a certain gap between the advanced level of foreign countries. For example, the study of knee motion disorders proprioceptive paresthesia and motor control caused by nerve injury still needs to be further strengthened. ${ }^{10}$

\section{CONCLUSION}

Rehabilitation treatment after $A C L$ reconstruction should follow the principles of early prevention, early rehabilitation, gradual, reasonable exercise intensity and differentiated treatment. Physicians should master the methods and skills of limb function exercise without over-emphasizing the braking force. This is because too much emphasis on braking is bound to cause tissue adhesion in the joint, hinder the blood circulation at the joint, slow functional recovery, and even cause joint flexion and extension limitation, which is not conducive to patient recovery. In addition, traditional Chinese medicine believes that after trauma, the muscles and bones of patients will be damaged, which will cause qi stagnation and blood, poor operation and other phenomena at the joints, and easy to appear hematumescence, pain and other symptoms. Over-emphasis on braking potential can exacerbate symptoms such as poor blood flow. Therefore, effective sports rehabilitation exercise should be carried out for patients, and rehabilitation exercise should be carried out as soon as possible under permitted conditions.

All authors declare no potential conflict of interest related to this article

AUTHORS' CONTRIBUTIONS: Each author made significant individual contributions to this manuscript. Aona Chen: writing and performing surgeries; Shuhua Qu: data analysis; Xuejun Ma: performing surgeries; Wenjiang Zhao: article review; Chenggen Guo: intellectual concept of the article.

\section{REFERENCES}

1. Kyoungkyu J. Comparison of knee laxity and isokinetic muscle strength in patients with a posterior cruciate ligament injury. J Phys Ther Sci. 2016;28(3):831-6.

2. Kim D, Jung J, Chung Y. The effects of performing bridge exercise and hip thrust exercise using various knee joint angles on trunk and lower body muscle activation in healthy subjects. Physical Therapy Rehabilitation Science. 2021;10(2):205-11.

3. Somthavil S. Altered kinematics after anterior cruciate ligament reconstruction, and their role in the prevention of osteoarthritis. International Journal of Therapy and Rehabilitation. 2018;25(10):529-37. doi: https://doi.org/10.12968/ijtr.2018.25.10.529.

4. Park SJ, Kim YM, Kim HR. The effect of hip joint muscle exercise on muscle strength and balance in the knee joint after meniscal injury. J Phys Ther Sci. 2016;28(4):1245-9.

5. Kim S. Comparative evaluation of ambulation patterns and isokinetic muscle strength for the application of rehabilitation exercise in patients with patellofemoral pain syndrome. J Phys Ther Sci. 2016;28(12):3279-82. doi: 10.1589/jpts.28.3279
6. Ali AA, Shalhoub SS, Cyr AJ, Fitzpatrick CK, Maletsky LP, Rullkoetter PJ, et al. Validation of predicted patellofemoral mechanics in a finite element model of the healthy and cruciate-deficient knee. J Biomech. 2016;49(2):302-9. doi: 10.1016/j.jbiomech.2015.12.020

7. Yazdanpanah $\mathrm{P}$, Mohammadi $\mathrm{H}$, Arjmand A, et al. Combined therapy in osteoarthritis of the knee double-blind randomized clinical trial. Annals of Physical \& Rehabilitation Medicine. 2018;61:e134-

8. Franz A, Becker J, Behringer M, Mayer C, Bittersohl B, Krauspe R, et al. Skeletal muscle health in osteoarthritis and total joint replacement therapy: Effects of prehabilitation on muscular rehabilitation. Dtsch Z Sportmed. 2019;2019(6):145-52. doi:10.5960/dzsm.2019.383.

9. Muraoka $\mathrm{H}$, Suzuki T. Effects of trunk anterior tilt and knee joint flexion angle changes on muscle activity in the lower limb muscles. J Phys Ther Sci. 2021;33(6):472-9. doi: 10.1589/jpts.33.472.

10. Lee JM, Lee JH. Benefits of using transcranial magnetic stimulation as a tool to facilitate the chronic knee injury rehabilitation. J Phys Ther Sci. 2017;29(4):733-6. doi: 10.1589/jpts.29.733. 